\title{
Review Article COVID-19 Infection in the Human Reproductive Tract of Men and Nonpregnant Women
}

Fabrício Morelli, Lyvia E. de F. Meirelles, Maria V. F. de Souza, Natália L. Mari, Cristiane S. S. Mesquita, Camila B. Dartibale, Gabrielle M. Z. F. Damke, Edilson Damke, Vânia R. S. da Silva, Raquel P. Souza, and Marcia E. L. Consolaro*

Department of Clinical Analysis and Biomedicine, Laboratory of Clinical Cytology and Semen Analysis, State University of Maringá, Maringá, Brazil

\begin{abstract}
SARS-CoV-2 is an enveloped non-segmented positive-sense RNA virus, classified as a beta coronavirus, responsible for the COVID-19 pandemic. Angiotensin-converting enzyme 2 (ACE2), reported as a SARS-CoV-2 receptor, is expressed in different human tissues (lung, intestine, and kidney) and in the testis, ovaries, uterus, and vagina. This suggests a potential risk to the human reproductive tract in COVID-19 patients. In addition, SARS-CoV-2 RNA has been detected in the blood, urine, facial/anal swabs, semen, and vaginal secretion, suggesting other potential means of transmission. However, little has been reported about SARS-CoV-2 infection in the male and nonpregnant female reproductive tracts, which may provide direct evidence on sexual transmission and fertility problems. Therefore, we focused this narrative review mainly on the distribution of ACE2 and SARS-CoV-2 positivity in the male and nonpregnant female reproductive tracts, providing an overview of the potential threat of COVID-19 to reproductive health and sexual transmission.
\end{abstract}

\section{INTRODUCTION}

Coronaviruses (CoV) are single-stranded RNA viruses presenting a crown-like aspect under an electron microscope. The coronavirus family includes several genera (from alpha to delta) with tropism for a variety of tissues and pathogenic potential against several animal species, being identified as human pathogens since the 1960s. ${ }^{1}$ SARS-CoV-2, previously known as the 2019 novel coronavirus, is an enveloped nonsegmented positive-sense RNA virus, classified as a beta coronavirus, rendering mammalian hosts susceptible to infection and responsible for the COVID-19 pandemic. Six other coronaviruses have been identified to infect human hosts, resulting in epidemics, including SARS-CoV and Middle East respiratory syndrome coronavirus (MERS-CoV). ${ }^{2}$ On February 11, 2020, the WHO announced a new name for the epidemic disease caused by SARS-CoV-2: COVID-19. On March 12, 2020, the global SARS-CoV-2 outbreak was declared a pandemic. $^{3}$ On November 26, 2020, the global count reached $59,816,510$ confirmed cases, with 1,410,378 COVID-19related deaths, ${ }^{4}$ causing growing public health concern. ${ }^{5}$

Clinically, COVID-19 presents a myriad of possible symptoms and outcomes from asymptomatic carriage, flu-like symptoms including cough, fever, general weakness, myalgia, pneumonia-like characteristics, and respiratory failure requiring mechanical ventilation. ${ }^{6-10}$ The COVID-19 rapid geographical spread, together with high transmissibility and serious clinical manifestations, ${ }^{11}$ led governments and health authorities to take serious measures to contain the pandemic. $^{12}$ In the meantime, researchers took global action on various objectives, including the study of viral transmission pathways and the search/validation of diagnostic methods to early identification of affected subjects. ${ }^{11,13,14}$

SARS-CoV-2 has a strong interaction capacity with the angiotensin-converting enzyme 2 (ACE2). ${ }^{5,13}$ The wide expression in different human tissues (lung, intestine, testicle,

\footnotetext{
${ }^{*}$ Address correspondence to Marcia E. L. Consolaro, Department of Clinical Analysis and Biomedicine, Laboratory of Clinical Cytology and Semen Analysis, State University of Maringá, Av. Colombo, 5790,
} Zona 7, Maringá 87020-900, Brazil. E-mail: melconsolaro@gmail.com and kidney) also justify different theoretical modes of viral transmission in addition to respiratory droplets. ${ }^{15}$ Some studies have revealed that ACE2 is present in the testis ${ }^{5,16-18}$ as well as in the ovaries, ${ }^{19-21}$ uterus, $^{20,22,23}$ and vagina, ${ }^{20}$ raising an urgent question of potential sexual transmission and consequences to reproductive health.

New evidence show that besides lungs, COVID-19 could also affect the human heart, ${ }^{6,24,25}$ liver, ${ }^{15,25}$ kidney, ${ }^{6,15,16}$ and nervous system. ${ }^{26,27}$ In fact, in addition to oropharyngeal swabs, SARS-CoV-2 RNA has also been detected in the blood, urine, facial/anal swabs, semen, and vaginal secretion, suggesting other potential means of transmission. ${ }^{28,29} \mathrm{Re}-$ cently, cases of COVID-19 during pregnancy have been reported. ${ }^{15,30,31}$ The results of recent review demonstrate that the maternal characteristics, clinical symptoms, maternal and neonatal outcomes of almost 11,000 cases of COVID-19, and pregnancy described in 15 different countries were not worse or different from those of the general population. ${ }^{31}$ However, the relatively small number of reported cases during pregnancy does not allow for a definitive conclusion on the aggressiveness of SARS-CoV-2 during pregnancy. Likewise, the influence of COVID-19 on the nonpregnant female reproductive tract needs further investigation. In addition, although there are studies pointing to the presence of viral RNA in semen samples, ${ }^{26,32}$ other studies indicated opposite results. ${ }^{12,33-36}$ Therefore, little has been reported about SARS-CoV-2 in the male and nonpregnant female reproductive tracts, which may provide direct evidence on sexual transmission and on reproductive health. Therefore, we focused this narrative review mainly on the distribution of ACE2 and SARS-CoV-2 positivity in the male and nonpregnant female reproductive tracts, providing an overview of the potential threat of COVID-19 to fertility and sexual transmission.

\section{DIFFERENT MODELS OF SARS-COV-2 TRANSMISSION}

The major clinical symptoms of the SARS-CoV-2 are influenza-like including fever, cough, headache, generalized myalgia, malaise, drowsiness, diarrhea, confusion, dyspnea, pneumonia, and rigorous shivering. ${ }^{37}$ The symptoms thus 
indicate that the viral infection likely contaminates and spreads primarily through the respiratory tract from human to human via respiratory droplets, direct and indirect physical contact, aerosol, or probably through the digestive tract, urine, and eyes and other routes. ${ }^{38}$

The well-established route of viral infection so far is through respiratory droplets and contact with COVID-19-affected individuals. ${ }^{39}$ The possibility of spread through other modes is continuously being explored, with some studies suggesting the SARS-CoV-2 spread through fecal-oral route, conjunctival secretions, flatulence (farts), sexual transmission, vertical transmission from the mother to fetus, and asymptomatic carriers $^{40}$ (Figure 1). Certain clinical procedures involving the upper airway such as obtaining a nose or throat swab, endotracheal intubation, manual ventilation, or nebulization are capable of generating particles $<5 \mu \mathrm{m}$, allowing for airborne transmission in healthcare settings. ${ }^{41}$ In particular, intensive care units have been associated with a higher risk of infection. Fomite transmission, the transmission from contact with contaminated surfaces, is possible with high rates of contamination of floors and the soles of healthcare staff as well as computer mice, doorknobs, and trash cans. ${ }^{42}$

Infection from direct contact with body fluids from infected individuals likely occurs via another route of transmission. ${ }^{43-48}$ However, documented evidence of transmission through these alternate sources remains unsubstantiated. ${ }^{43}$ In these contexts, a probable route of transmission could be through sexual intercourse. ${ }^{40}$ This supposition has mainly arrived after the reporting of fecal-oral transmission of SARS-CoV-2. ${ }^{29}$ It is assumed that certain sexual behaviors could even result in alternative ways of transmission by both direct and indirect exposure of oral-anal contact within few days after recovery because the gastrointestinal tract may continue shedding the viral RNA. ${ }^{49}$ In favor of this hypothesis, SARS coronavirus has been known to cause impairment to multiple organs including inflammation of human testes/orchitis. Coronaviruses are also known to cause defects in spermatogenesis, ${ }^{50}$ and SARSCoV-2 RNA has been detected in semen ${ }^{26}$ and vaginal secretion. ${ }^{51}$ In addition to the impact of SARS-CoV-2 sexual transmission on the viral dispersion, the possible influence of sexual transmission to pregnant women should also be considered. Vivanti et al. ${ }^{52}$ demonstrated the transplacental transmission of SARS-CoV-2 in a neonate born of a mother infected in the last trimester and presenting neurological compromise. In addition, in a recent a systematic review of 108 pregnancies, Zaigham and Anderson ${ }^{53}$ concluded that although most of the mothers were discharged without any major complications, severe maternal morbidity and perinatal death might occur in COVID-19 disease. The authors concluded that vertical transmission of the COVID-19 could not be ruled out.

Despite being a plausible hypothesis, up to now, there are no reports of sexual transmission of SARS-CoV-2. However, considering the possible impacts of SARS-CoV-2 sexual transmission, as well as the possibility that this virus could affect reproductive health, we will review reported studies in this area to understand whether the reproductive tract of men and women could be vulnerable to SARS-CoV-2 infection or not.

\section{SARS-COV-2 AND ITS HUMAN HOST RECEPTOR}

SARS-CoV-2 has four structural proteins, namely, nucleocapsid (N), spike (S), envelope (E), and membrane (M) proteins. The $S$ protein is required to fuse to the host cell through the receptor-binding domain. ${ }^{54}$ Among these proteins, the trimeric $S$ protein is indispensable for virus-cell receptor interactions during viral entry. ${ }^{55,56}$ The $S$ protein comprises an $N$-terminal S1 subunit responsible for virus-receptor binding and a $C$-terminal S2 subunit responsible for virus-cell membrane fusion. $\mathrm{S} 1$ is further divided into an $\mathrm{N}$-terminal domain and a receptor-binding domain (RBD). ${ }^{57,58}$ SARS-CoV-2 targets cells through the $S$ protein, which binds to the human ACE2 receptor and uses the cellular serine protease transmembrane protease serine 2 (TMPRSS2) for $S$ protein priming $^{59-63}$ (Figure 2A). Such binding triggers a cascade of events leading to fusion between the cellular and viral membranes for cell entry. The viral RNA genome is released into the cytoplasm after membrane fusion. Polyproteins are subsequently synthesized to encode the viral replicasetranscriptase complex, and then, the viral RNA is synthesized by the RNA-dependent RNA polymerase. The synthesis of structural proteins is followed by viral particle assembly and release. . $^{5,63}$

In theory, organs with a high expression of ACE2 or TMPRSS2 are more vulnerable to infection. Currently, the respiratory, cardiovascular, digestive, and urinary systems have been reported as potential target organs for SARS-CoV2 infection. ${ }^{64}$ TMPRSS2 are then needed to cleave the viral S protein to induce a conformational change to $S$ that allows for permanent fusion of the viral and host cell membranes. ${ }^{60,65}$ The importance of TMPRSS2 has been confirmed in studies

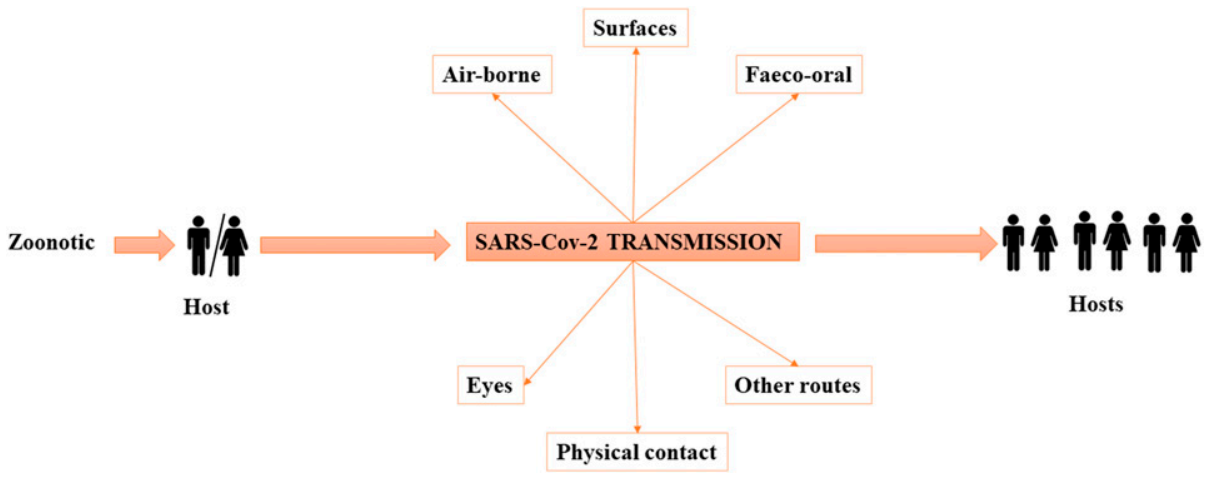

FIGURE 1. Diagrammatic representation of different models of SARS-CoV-2 transmission. This figure appears in color at www.ajtmh.org. 


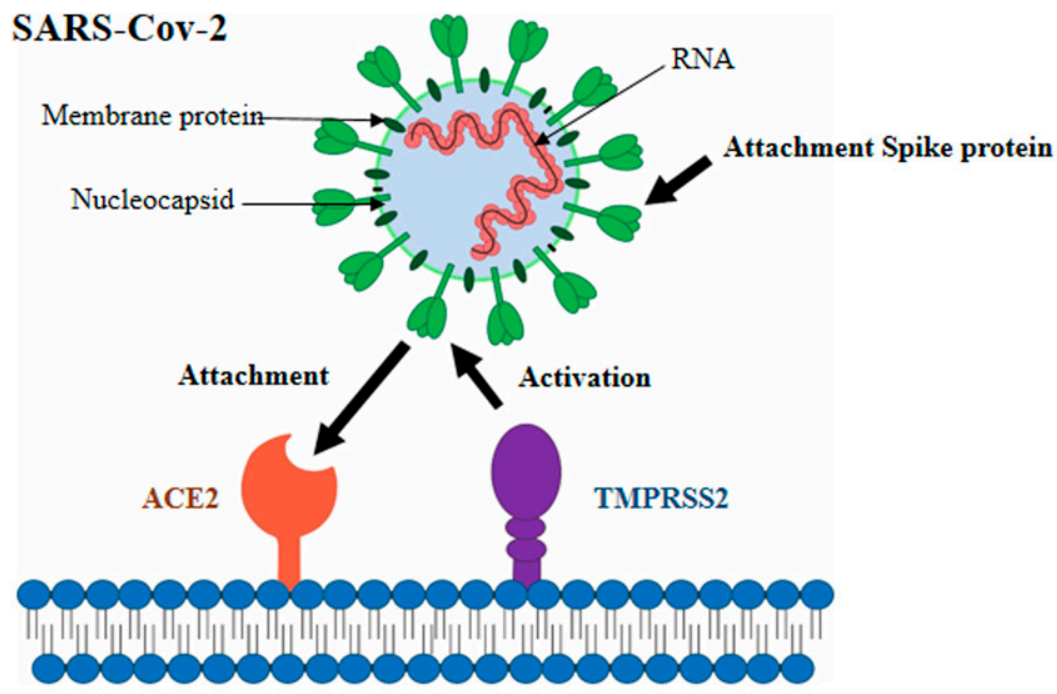

B

ACE2 gene location (Human)

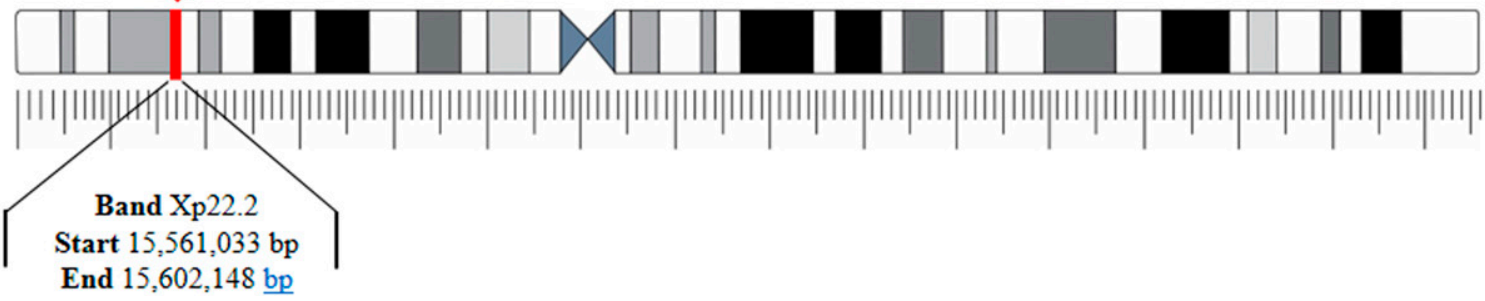

Chromosome X

FIGURE 2. Schematic representation of SARS-CoV-2 entry into the cells by the angiotensin-converting enzyme 2 (ACE2). (A) SARS-CoV-2 targets cells through the $S$ protein, which binds to the human ACE2 receptor and uses the cellular serine protease TMPRSS2 for S protein priming. ${ }^{13}$ (B) ACE2 gene location in chromosome $X$ on the Xp22.2 band. ${ }^{66,67}$ This figure appears in color at www.ajtmh.org.

showing that its inhibition blocks SARS-CoV-2 entry and spread in targeted lung cells. ${ }^{60}$ However, TMPRSS2 is more broadly expressed in human tissues than ACE2, indicating that ACE2 may be one of the main determinants of whether a given cell type is susceptible to viral infection. ${ }^{24}$

Angiotensin-converting enzyme 2, is attached to the cell membrane of tissues like the cardiovascular system, lungs, kidney, and gastrointestinal system. ${ }^{66,67}$ In addition, it has been reported that some other tissues like the male testis and female breast also present ACE2. ${ }^{5,16,17}$ Angiotensinconverting enzyme 2 is located on Xp22.2 (Figure 2B) and encoded an 805-amino acid long protein and belongs to the family of the angiotensin-converting enzyme of dipeptidyl carboxydipeptidases. ${ }^{66,67}$ Angiotensin-converting enzyme 2 contains a 17 -amino acid $N$-terminal signal peptide and a 22-amino acid $C$-terminal membrane anchor. It also has a conserved motif at the zinc metalloprotease consensus sequence $(\mathrm{HEXXH})$ and a conserved glutamine residue at Glu-402 that served as a third zinc ligand. ${ }^{66}$ Angiotensinconverting enzyme 2 is also homologous to the human ACE, which plays a role in cleaving angiotensin I into angiotensin $1-9$, and vasoconstrictor angiotensin II peptide into the vasodilator angiotensin 1-7 (Ang [1-7]). ${ }^{68,69}$ By cleaving angiotensin II and increasing vasodilator Ang (1-7), it may act as an important regulator of heart function ${ }^{66,70}$ and plays a protective role in acute lung injury. The organ- and cell-specific expression of ACE2 imply its regulatory role in cardiovasculature, kidneys, and fertility. ${ }^{71,72}$ In relation to fertility, the expression of ACE2 in the ovaries and testes suggests that it plays a regulatory role in steroidogenesis, and thus affects germ cells and reproductive health. ${ }^{73}$

Angiotensin-converting enzyme 2 acts as the entry point into cells for several coronaviruses. ${ }^{74}$ Diseases associated with the ACE2 gene include SARS-CoV, COVID-19, and Hartnup disorder. ${ }^{2,59,73}$ More specifically, the SARS-CoV-2 presented a similar RBD structure to SARS-CoV, and binding affinity between ACE2 and SARS-CoV-2 is nearly 10- to 20fold higher than that between ACE2 and SARS-CoV. ${ }^{5,75,76}$ Hence, in ACE2-expressing cells and tissues, ACE2 is the functional receptor of SARS-CoV-2 and plays a critical role in the viral entry into the cells during infection. ${ }^{55,77-79}$

\section{SARS-COV-2 AND THE HUMAN MALE REPRODUCTIVE TRACT}

The correlation between SARS-CoV-2 infection and the male genital tract has not yet been established. However, there are some initial signs. These pieces of initial evidence 
focused on two main aspects which are the detection of ACE2 and SARS-CoV-2 in the human male reproductive tract, which is discussed in the following text.

Angiotensin-converting enzyme 2 in the human male reproductive tract. Some studies analyzed the ACE2 receptors and/or transcripts in the human male genital tract (Table 1), as follows. About two decades before, a study of Donoghue et al. ${ }^{70}$ revealed that an ACE2 transcript was expressed only in the heart, kidney, and testis of 23 human tissues. Around 10 years later, Reis et al. ${ }^{80}$ detected the ACE2producing Ang (1-7) and its receptor Mas in the testis, mainly in the interstitial compartment and cytoplasm of the Leydig cells. They further demonstrated the strong influence of ACE2 in the male reproductive tract by showing that humans with severe spermatogenesis impairment have lower levels of ACE2, Ang-(1-7), and Mas than fertile subjects. Thereafter, only recently, new research studies emerged in this field because of the pandemic of COVID-19, as follows.

Wang and $\mathrm{Xu}^{16}$ showed that ACE2 was predominantly enriched in spermatogonia, Leydig cells, and Sertoli cells. Accordingly, Stanley et al. ${ }^{21}$ found ACE2 expression in myoid cells, spermatogonial stem cells, and Leydig cells. In addition, Fu et al. ${ }^{17}$ showed that ACE2 was highly expressed in Leydig cells and cells in the seminiferous ducts.

Regarding the co-expression of ACE2 and TMPRSS2 in human testicles, in the study of Stanley et al., ${ }^{21}$ these coexpression was not detected in testicular cells and sperms, and a correlation between ACE2 and TMPRSS2 expression was not observed in any of the annotated cell types or testicular cells broadly. In addition, the results of Pan et al. ${ }^{35}$ demonstrated sparse expression of ACE2 and TMPRSS2 in the human testis, with almost no overlapping gene expression. The results of these studies reinforce the hypothesis that once TMPRSS2 is more broadly expressed in human tissues than ACE2, it is possible that ACE2 may be one of the main determinants of whether a given cell type is susceptible to viral infection. ${ }^{24}$ If this hypothesis is correct, the expression of ACE2 alone may be more important than the co-expression of ACE2 and TMPRSS2 in the susceptibility of human testicles to SARS-CoV-2.

As far as we know, only the study conducted by Song et al. ${ }^{81}$ evaluated ACE2 and TMPRSS2 expression at locations in the male genital tract other than the testes and sperms. This study showed that TMPRSS2 was highly expressed, and ACE2 expression was very low, but the two receptors were coexpressed in at least a small percentage of prostate hillock cells; therefore, a prostate infection by SARS-CoV-2 cannot be excluded. These data suggest that the accessory glands could be a second possible site of infection by SARS-CoV-2 in the male reproductive tract, particularly the prostate.

In general, the aforementioned studies only evaluated the expression of ACE2 and/or its transcripts in the male genital tract, but not its influence on male reproductive pathophysiology. In this sense, Shen et al. ${ }^{18}$ showed that ACE2 was expressed in both germ cells and somatic cells, among which are Sertoli cells, spermatogenic stem cells, and Leydig cells. Moreover, they also found that the positive rate of ACE2 in testes of infertile men was higher than that of normal men, indicating that SARS-CoV-2 may cause reproductive disorders through a pathway activated by ACE2, and men with reproductive disorders may be more likely infected by SARSCoV-2. In addition, they showed that the expression level of ACE2 was associated with the age of the man, and the peak of positive rate was 30 years, which indicates that young men are more likely to be infected by SARS-CoV-2. Accordingly, Liu et al. ${ }^{5}$ observed that the level of ACE2 expression decreased with the increase in age and that ACE2 expressing cells existed in almost all testes cell types and that Sertoli cells had the highest expression level. Furthermore, they showed that the ACE2 expression level in nonobstructive azoospermia patients' Sertoli cells was significantly decreased.

Overall, the studies presented in this section indicated that in the human male reproductive tract, the testis should probably be the organ in the male reproductive tract most vulnerable to SARS-CoV-2 infection mainly because of its high ACE2 expression. Angiotensin-converting enzyme 2 receptors are present in spermatogonia, seminiferous tubules and Sertoli, Leydig, and prostate epithelial cells, albeit its role needs to be better clarified.

SARS-CoV-2 positivity in the human male reproductive tract. In conditions of viremia, virus may seed into the male reproductive tract because the blood-testis barrier may not completely isolate the virus. ${ }^{82}$ A wide breadth of viruses, such as Zika, Ebola, and Marburg viruses, have been found in male testes and semen. ${ }^{83}$ Virus-induced testis damage can impair gonadal hormone secretion and spermatogenesis, as seen in HIV or mumps-induced orchitis. ${ }^{84}$ A previous study on SARS suggested the SARS-CoV can cause orchitis ${ }^{85}$; however, little

TABLE 1

Angiotensin-converting enzyme 2 receptor and SARS-CoV-2 RNA detection in the male reproductive tract

\begin{tabular}{|c|c|c|c|c|}
\hline \multirow[b]{2}{*}{ Reproductive tract locus } & \multicolumn{2}{|l|}{ ACE2 receptor } & \multicolumn{2}{|r|}{ SARS-CoV-2 RNA } \\
\hline & Positive & Negative & Positive & Negative \\
\hline Semen & - & - & Li et al. ${ }^{26}$ & $\begin{array}{l}\text { Kayaaslan et al. }{ }^{89} \text {; Pavone et al. }{ }^{90} \text {; Pan } \\
\text { et al. }^{35} \text {; Song et al. }{ }^{36} \text {; Holtimann et al. }{ }^{33} \text {; } \\
\text { Paoli et al. }{ }^{12} \text {; Ma et al. }{ }^{34}\end{array}$ \\
\hline Testes & $\begin{array}{l}\text { Donoghue et al. }{ }^{70} \text {; Reis et al. }{ }^{79} \text {; Pan } \\
\text { et al. }\end{array}$ & - & Yang et al. ${ }^{32}$ & Song et al. ${ }^{36}$ \\
\hline Seminiferous ducts & Fu et al. ${ }^{17}$ & - & - & - \\
\hline Interstitial compartment & Reis et al. ${ }^{79}$ & - & - & - \\
\hline Leydig cells & Wang and $\mathrm{Xu}{ }^{16}$; Fu et al. ${ }^{17}$; Shen et al. ${ }^{18}$ & - & - & - \\
\hline Sertoli cells & Wang and $X u^{16}$; Liu et al. ${ }^{5}$; Shen et al. ${ }^{18}$ & - & - & - \\
\hline Spermatogonia & $\begin{array}{l}\text { Wang and } \mathrm{Xu}^{16} \text {; Shen et al. }{ }^{18} \text {; Stanley } \\
\text { et al. }{ }^{21}\end{array}$ & - & - & - \\
\hline Prostate & Song et al. ${ }^{81}$ & - & - & Zhang et al. ${ }^{71}$ \\
\hline
\end{tabular}

ACE2 = angiotensin-converting enzyme 2 . 
is known about the presence of SARS-CoV-2 in biological fluids and tissues of the male genital tract and its possible relation with reproductive health. To date, few studies have assessed the presence of SARS-CoV-2 in the human male genital tract (Table 1), which will be described in detail as follows.

Two studies presented SARS-CoV-2 positivity in the human male reproductive tract. Li et al. ${ }^{26}$ enrolled a total of 38 patients, of whom 23 were clinically recovered and 15 were in the acute stage of infection. Six patients were positive for SARSCoV-2 in the semen, four of these patients were in the acute stage of infection and two were already recovered. In the second study, carried out by Yang et al., ${ }^{32}$ the objective was to determine the pathological changes and whether SARS-CoV2 could be detected in the testes of deceased COVID-19 patients. They performed a postmortem examination of the testes from 12 COVID-19 patients using reverse transcriptase PCR (RT-PCR) to detect the virus in the testicular tissue. The authors showed that the testes from COVID-19-positive patients exhibited significant seminiferous tubular injury, reduced Leydig cells, and mild lymphocytic inflammation. They showed no evidence of SARS-CoV-2 in the testes of the majority (90\%) of the cases by RT-PCR and in none by electron microscopy.

Regarding these two studies, it is important to highlight that the viral viability and infectivity were not determined. However, both studies presented the possibility of SARS-CoV-2 be seeded into the male reproductive tract, at least in some cases. This hypothesis is supported by prior knowledge that viremic patients can shed viruses into semen (27 viruses detected to date) ${ }^{86}$ including Zika virus (ZIKV), which remains in the semen of symptom-free men for up to 1 year post-recovery. ${ }^{87}$ Importantly, ZIKV infection modifies semen characteristics in men, and replication-competent virus can be isolated from motile spermatozoa. ${ }^{88}$

On the other hand, the other studies that investigated the presence of SARS-CoV-2 in the semen, ${ }^{12,33,35,36,89,90}$ testicles, ${ }^{36}$ and the prostatic secretion ${ }^{71}$ did not detect the virus. However, these studies vary according to the stage of COVID19 and the severity of the patients' infection. These studies are discussed in the following text.

Kayaaslan et al. ${ }^{89}$ aimed to investigate the presence of SARS-CoV-2 RNA in the semen of patients with a positive nasopharyngeal swab test for SARS-CoV-2 in the acute stage. Sixteen patients were included in the study, and all semen samples were negative for SARS-CoV-2 RT-PCR. Pavone et al. ${ }^{90}$ tried to determine whether SARS-CoV-2 was detectable in the semen of Italian patients showing mild or no symptoms of COVID-19 at the time of sampling. The seven patients were considered convalescent and two in the acute phase of infection. Results of RT-PCR in the semen showed no evidence of SARS-CoV-2 RNA in the nine patients enrolled. Song et al. ${ }^{36}$ conducted a study by examining SARS-CoV-2 RNA in semen samples collected from 12 patients (aged between 22 and 38 years) in their recovery phase, as well as in testicular samples from one patient who died of COVID-19 during the acute phase. The results showed that the SARSCoV-2 was absent from the semen and testes in men infected with COVID-19 at both acute and recovery phases. In the study conducted by Pan et al., ${ }^{35}$ SARS-CoV-2 was not detected in the semen of patients recovering from COVID-19 1 month after COVID-19 diagnosis. Paoli et al. ${ }^{12}$ included only a 31-year-old patient positive for COVID-19. A semen sample was collected 27 days after the onset of symptoms and also presented negative for SARS-CoV-2.

Two studies evaluated the presence and relevance of SARS-CoV-2 in semen parameters. Holtmann et al. ${ }^{33}$ investigated semen and a blood sample collected from 34 men that were distributed as follows: 1) patients in convalescence (patients with confirmed SARS-CoV-2 infection in the pharyngeal swab according to RT-PCR or antibodies), 2) negative control group (no antibodies), and 3) patients with acute infection (detection of SARS-CoV-2 in pharyngeal swab). No RNA was detected by means of RT-PCR in the semen, including semen samples from two patients with acute COVID19 infection. However, patients with a moderate infection presented a statistically significant impairment of sperm quality (sperm concentration, total number of sperm per ejaculate, total number of progressive motility, and total number of complete motility) compared with men recovered from a mild infection and the control group. Ma et al. ${ }^{34}$ collected semen specimens from 12 COVID-19 male patients for viral detection and semen characteristics analysis. No SARSCoV-2 was detected in semen specimens. Regarding the semen quality, eight of the 12 patients presented normal results. They also compared the sex-related hormone levels between 119 reproductive-aged men with SARS-CoV-2 infection and 273 age-matched control men. A higher serum luteinizing hormone (LH) and a lower ratio of testosterone to LH were observed in the group positive for COVID-19. The authors concluded that COVID-19 patients presented an abnormal sex hormone secretion, suggesting that attention should be given to the reproductive function evaluation in the follow-up. Regarding the impairment of semen quality demonstrated in these two studies, there is a possibility that SARS-CoV-2 has a direct impact on sperm as follows. The renin-angiotensin-aldosterone system (RAAS) is one of the cell signaling systems that regulate spermatogenesis. ${ }^{91}$ Several RAAS family ligand enzymes and receptors are present in human spermatozoa, including angiotensin converting enzyme (ACE) 1 and 2, angiotensin receptor type 1 and type 2 and the Ang (1-7) mitochondrial assembly receptor (Ang-[1-7]/ MasR). ${ }^{92}$ Attack of SARS-CoV-2 on this sperm surface signaling system could elicit multiple deleterious local responses. The impact of the virus on spermatozoa ACE2 activity would probably enhance angiotensin II levels and increase reactive oxygen species (ROS) production, installing a state of apoptosis and cell senescence. ${ }^{93}$ SARS-CoV-2 infection may also affect sperm DNA through induction of oxidative stress or altering reproductive endocrinologic milieu. ${ }^{94}$

Finally, to delineate whether the SARS-CoV-2 could be detected in the expressed prostatic secretion (EPS), 10 male patients with confirmed COVID-19 were recruited in a study conducted by Zhang et al. ${ }^{71}$ All patients were stratified into two groups: one group with positive nasopharyngeal swabbing for SARS-CoV-2 within 3 days of the EPS taken day $(n=3)$ and the other group with previously positive nasopharyngeal swabbing for SARS-CoV-2 but turned negative before the taken day $(n=7)$. None of the COVID-19 patients were positive for SARS-CoV-2 RNA in EPS.

The studies presented here (Figure $3 A$ ) showed that the positivity and consequences of SARS-CoV-2 infection in the male reproductive tract have been little evaluated, and it is not known about which cell type SARS-CoV-2 targets in this site. 
A

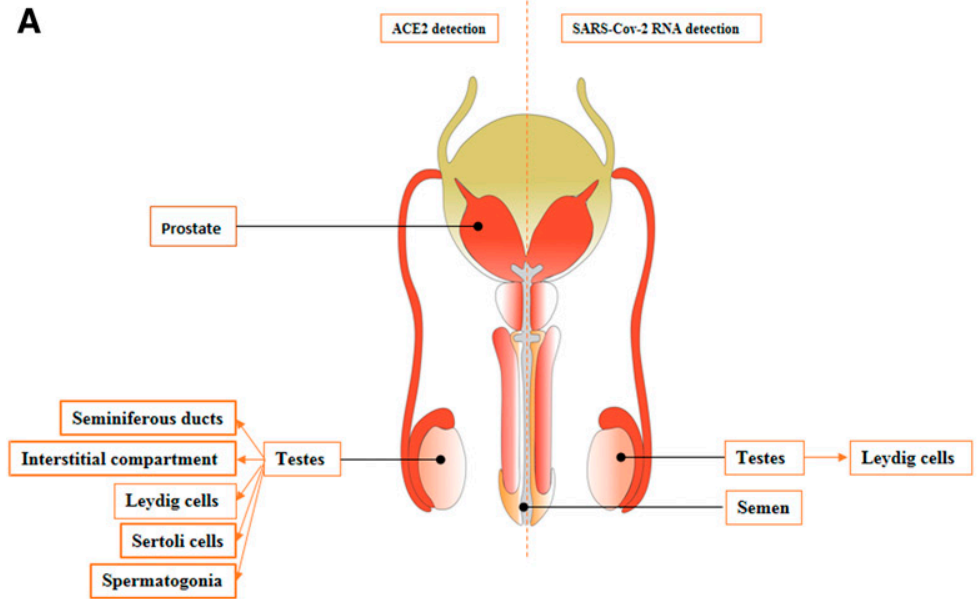

B

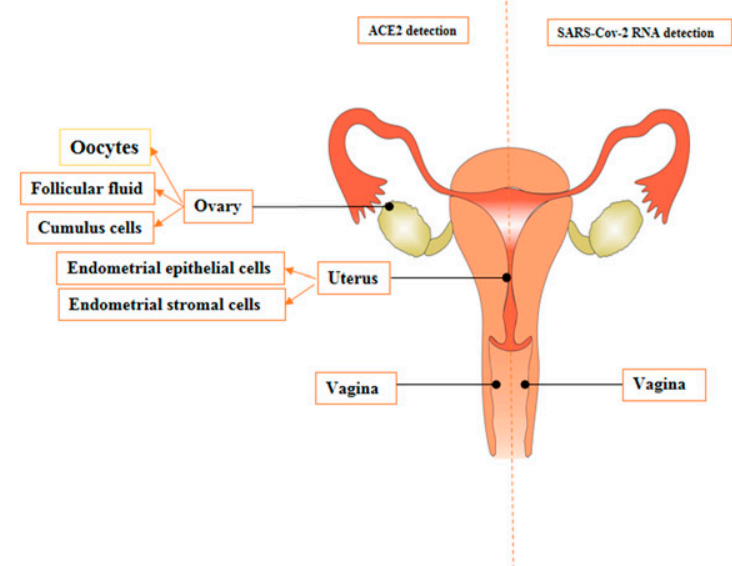

FIGURE 3. Schematic representation of the potential location of the ACE2 receptor and SARS-CoV-2 RNA in the human reproductive tract of men (A) and nonpregnant women (B). This figure appears in color at www.ajtmh.org.

In addition, among the described studies, it is possible that there are variations regarding the presence of SARS-CoV-2 in the male reproductive tract. However, some studies have reported the virus to be present in the testicular seminal duct and semen, compromising the safety of sexual intercourse. Considering that $80 \%$ of those infected have mild symptoms or are asymptomatic, it is advisable to take some precautions at least during quarantine. The use of condoms and noncoital behavior that does not involve direct contact with the semen are recommended. ${ }^{95}$ Still, few studies have addressed the possibility of andrological consequences in infected patients. According to Blumenfeld, ${ }^{96}$ several additional questions need urgent answers for the general public: How long should they abstain from intercourse? Are condoms protective enough? Are the medical laboratory workers and personnel in contact with infertile patients' semen, for intrauterine insemination or assisted reproductive technologies (ARTs), at risk of acquiring the infection? If the semen may be infectious, would the generated embryos and the female partners be at risk of acquiring SARS-CoV-2? What are the possible remote consequences to the future infants? Therefore, these and many other questions need answers, and further studies with a larger number of infected subjects, including young patients, to determine possible short- and long-term SARS-CoV-2 consequences for male reproductive health and the possibility of sexual transmission are required.

\section{SARS-COV-2 AND THE NONPREGNANT FEMALE REPRODUCTIVE TRACT}

The correlation between SARS-CoV-2 infection and the nonpregnant female reproductive tract has been even less studied than the male reproductive tract. Therefore, as the impact of SARS-CoV-2 infection has been already demonstrated for multiple organs, it would be reasonable to hypothesize the potential impact in the female genital tract as well. ${ }^{72}$ As for the male reproductive tract, we will focus the discussions on two main aspects: the detection of ACE2 and SARS-CoV-2 in the reproductive tract of nonpregnant women.

Angiotensin-converting enzyme 2 in the reproductive tract of nonpregnant women. Few studies have evaluated the ACE2 receptors and/or transcripts in the nonpregnant female reproductive tract (Table 2), as follows. Angiotensinconverting enzyme 2 mRNA transcripts were detected in ovaries from reproductive-age and postmenopausal women by Reis et al. ${ }^{19}$ These authors also described that the Ang(1-7) peptides, which are produced by ACE2, are located in several ovarian compartments and may be quantified in

TABLE 2

Angiotensin-converting enzyme 2 receptor and SARS-CoV-2 RNA detection in the nonpregnant female reproductive tract

\begin{tabular}{|c|c|c|c|c|}
\hline \multirow[b]{2}{*}{ Reproductive tract locus } & \multicolumn{2}{|l|}{ ACE2 receptor } & \multicolumn{2}{|c|}{ SARS-CoV-2 RNA } \\
\hline & Positive & Negative & Positive & Negative \\
\hline Vagina & Jing et al. ${ }^{20}$ & - & Scorzolini et al. ${ }^{91}$ & Qiu et al. ${ }^{99}$ Cui et al. ${ }^{100}$ \\
\hline Uterus & Jing et al. ${ }^{20}$ & Goad et al. ${ }^{98}$ & - & - \\
\hline Endometrium & Henarejos-Castillo et al. ${ }^{97}$ & - & - & - \\
\hline Endometrial epithelial cells & Vaz-Silva et al. $^{22}$ & - & - & - \\
\hline Endometrial stromal cells & Vaz-Silva et al. ${ }^{22}$; Chadchan et al. ${ }^{23}$ & - & - & - \\
\hline Myometrium & - & Goad et al. ${ }^{98}$ & - & - \\
\hline Fallopian tube & - & Goad et al. ${ }^{98}$ & - & - \\
\hline Ovary & Reis et al. ${ }^{19}$; Jing et al. ${ }^{20}$ & Goad et al. ${ }^{98}$ & - & - \\
\hline Oocyte & Jing et al. ${ }^{20}$ & - & - & - \\
\hline Follicular fluid & Reis et al. ${ }^{19}$ & - & - & - \\
\hline Cumulus cells & Stanley et al. ${ }^{21}$ & - & - & - \\
\hline
\end{tabular}


follicular fluid. Stanley et al. ${ }^{21}$ found that ACE2 was shown to have wide expression in human cumulus cell samples. Jing et al. ${ }^{20}$ found that ACE2 is most abundantly expressed in the ovary and that the expressional level of ACE2 in oocytes is relatively high. In addition, the same authors found ACE2 in the uterus and vagina. This was the only study that evaluated ACE2 expression in the lower reproductive tract of nonpregnant women.

Angiotensin-converting enzyme 2 mRNA was also identified in the uterus of women by Vaz-Silva et al. ${ }^{22}$ They showed that ACE2 expression is more abundant in epithelial cells than stromal cells and in the secretory than the proliferative phase. Accordingly, Chadchan et al. ${ }^{23}$ found that in the human tissue, ACE2 was expressed in both endometrial epithelial and stromal cells in the proliferative phase of the menstrual cycle, and the expression increases in stromal cells in the secretory phase. According to the authors, SARS-CoV-2 may be able to enter into endometrial stromal cells and elicit pathological manifestations in women with COVID-19. If so, women with COVID-19 may be at increased risk of early pregnancy loss. Conversely, Henarejos-Castillo et al. ${ }^{97}$ showed that gene expression was medium for TMPRSS2 and low for ACE2. Angiotensin-converting enzyme 2 expression increased toward the window of implantation, but TMPRSS2 was not significantly changed across the cycle. So, ACE2 expression increased with age, especially in early phases of the cycle.

Finally, Goad et al. ${ }^{98}$ presented contrary results to other authors. They investigated the prevalence of SARS-CoV-2 receptors among reproductive tissues from the uterus, myometrium, ovary, fallopian tube, and breast epithelium. However, either ACE2 or TMPRSS2 expressions were not significantly detected in the myometrium, uterus, ovaries, fallopian tube, or breast.

In general, most of the studies discussed in this section indicated that the upper reproductive tract of nonpregnant women is vulnerable to SARS-CoV-2 infection mainly because of its ACE2 expression in the ovary and uterus, albeit its role needs to be better clarified. However, one study did not show the ACE2 receptor in the upper genital tract. These discrepancies are possibly due to the methodological differences among these studies. Therefore, future studies are still needed for further clarification in this area. Still, considering that only one study evaluated the expression of ACE2 in the lower reproductive tract, ${ }^{20}$ further studies are urgently needed to clarify the possibility of SARS-CoV-2 sexual transmission via vagina.

SARS-CoV-2 positivity in the reproductive tract of nonpregnant women. So far, to our knowledge, only four studies $^{51,99-101}$ evaluated SARS-CoV-2 shedding in the reproductive tract of nonpregnant women (Table 2). In three of them, SARS-CoV-2 was investigated in vaginal samples ${ }^{51,99,100}$ and in another, in vulvar ulcers. ${ }^{101}$ These studies are described in detail as follows.

Scorzolini et al. ${ }^{51}$ described that in their initial case series of three patients with laboratory-confirmed COVID-19 (two males and one female), a 65-year-old woman traveling from Wuhan city during January 2020 had the vaginal fluid tested for SARS-CoV-2. After two previous negative results, a vaginal swab was positive by RT-PCR on days 7 and 20 after symptom onset with a cycle threshold of 37.2 and 32.9 , respectively. According to the authors, although the transmission of SARSCoV-2 through genital secretion has not yet been established and their results are limited to molecular detection only, they support the indication to perform cesarean section to reduce the risk of vertical transmission at delivery.
On the other hand, SARS-CoV-2 was not detected by Qiu et al. ${ }^{99}$ and Cui et al. ${ }^{100}$ in vaginal samples of nonpregnant women. In the study of Qiu et al., ${ }^{99}$ vaginal swabs of 10 postmenopausal patients with severe COVID-19 were evaluated by RT-PCR between 17 and 40 days from symptom onset. None of the samples were positive, even when the patients' respiratory symptoms were severe. The authors suggested that the likelihood of transmitting SARS-CoV-2 to sexual partners through virus in vaginal fluids is low. The second study was conducted by Cui et al., ${ }^{100}$ and the possible presence of SARS-CoV-2 in the vaginal fluid and cervical exfoliated cells of 35 female COVID-19 patients was also studied. The stage of infection was not described at the time of genital collections. All the vaginal and cervical samples tested were negative for SARS-CoV-2.

Falkenhain-López et al. ${ }^{101}$ reported the first case of a woman with COVID-19-related acute genital ulcers (AGU). In detail, the authors described the clinical case of a 41-year-old otherwise healthy woman with a 5-day history of painful genital ulcers. She also presented dry cough and rhinorrhea. Any medication was taken by the patient before the development of the lesions, and she denied any recent sexual risk behavior. A single oral aphtha was also observed. Treatment with prednisone $30 \mathrm{mg}$ daily was initiated. One week later, the patient returned referring to improvement of the genital ulcers with pain reduction and complete resolution of the oral aphtha. However, she presented worsening of cough and a 3-day history of chest pain, low-grade dyspnea, and dysthermia. SARS-CoV-2 RT-PCR performed on a nasopharyngeal swab and genital ulcers returned positive, and COVID-19 diagnosis with AGU was made. Genital ulcers evolved to resolution after one more week of corticosteroid treatment. The authors suggested that AGU could be triggered by SARS-CoV-2, comparably to other respiratory virus infections.

Studies presented in this section showed that in comparison to the male reproductive tract, the positivity and consequences of SARS-CoV-2 infection on the reproductive tract of nonpregnant women have been scarcely evaluated (Figure 3B). Most commonly, studies on the women reproductive tract evaluated SARS-CoV-2 infection in pregnant women because of the possible relationship between the SARS-CoV-2 congenital and childbirth transmission. 2,30,102 In addition, the new finding about the SARS-CoV-2 detection in the vaginal secretion increases the possibility that sexual intercourse could be an additional direct vector of infection, adding to the recent evidence of a likely fecal-oral transmission vector ${ }^{103}$ or indirectly by exposure of the rectal mucosa to saliva. ${ }^{104}$ However, several important questions about SARSCoV-2 RNA detection in the reproductive tract of nonpregnant women need to be answered given as follows: Does the virus have tropism to any specific cell? What is the viral load and how long does the virus remain infectious? How long do women need to wait to become pregnant? And what is the long-term damage to women? To answer these and other questions, further studies are urgently needed to determine the actual infection rate and the kinetics of SARS-CoV-2 infection in the female reproductive tract of nonpregnant women.

\section{COVID-19 AND ASSISTED REPRODUCTION}

Regarding the ARTs, there are two main aspects of fundamental importance. First, although there is a potential risk for disease transmission at several stages of ART, little is known 
about it. SARS-CoV-2 transmission may be facilitated by ART, especially by intracytoplasmic sperm injection (ICSI). Although most of the ARTs involve washing and repeated dilution of the semen sample, virus particles could theoretically be transmitted directly via ICSI. ${ }^{105,106}$ Usually in ARTs, the semen preparation by bilayer density gradient centrifugation coupled with ICSI is known to decrease the virus transmission risks. However, it is already known that hepatitis $\mathrm{C}$ virus (HCV) is not present in the last fraction used for ARTs, ${ }^{105}$ whereas ZIKV and other viruses such as HIV and hepatitis B virus (HBV) could persist in this fraction. ${ }^{106}$ SARS-CoV-2 could be present in semen samples and liquid nitrogen in cryostores across the world. Therefore, it is recommended that utmost precaution be exercised for sperm cryobanking at this time, with use of highly secure devices and segregated cryovessels. ${ }^{107}$ On a positive note, to date, there has never been a recorded case of viral cross-contamination between cryopreserved clinical semen samples, so the risk of SARS-CoV-2 cross-contamination between semen samples is negligible. ${ }^{108}$ In addition, possible effects on early embryogenesis and development must also be considered. ${ }^{106}$ Therefore, good standard laboratory practices should be strictly applied when handling gametes and embryos within the embryology and andrology laboratories. ${ }^{109}$

Second, there is the necessity of recommendations for patients using ARTs in view of the COVID-19 pandemic. Before ART treatments, it is very important to consider local and national regulations. In this sense, on March 17, the American Society of Reproductive Medicine provided early key recommendations, updated and affirmed on July 10, including suspending initiation of new treatment cycles. ${ }^{110}$ The group also recommended canceling planned embryo transfers, suspending elective surgeries, nonurgent diagnostic procedures, and minimizing in-person interaction by increasing telemedicine contact. Only patients undergoing emergency procedures, such as those for fertility preservation, and patients already undergoing cycle stimulation should complete their treatments, but they should be advised to cryopreserve their embryos and not receive a fresh embryo transfer.

On March 19, the European Society of Human Reproduction and Embryology recommended a precautionary approach. They advised all infertile patients considering or planning treatment to avoid becoming pregnant at this time, albeit there is no strong evidence of negative effects of COVID-19 on pregnancy, especially at the early stages. ${ }^{111}$ They further suggested consideration of deferred pregnancy with oocyte or embryo cryopreservation. In the United Kingdom, the Human Fertilization and Embryology Authority (HFEA) published their guidance on March 18, calling for a need to stop fertility treatments over the coming weeks to minimize the spread of the virus and to reduce the impact on the healthcare services because of possible complications of assisted reproduction, such as ovarian hyperstimulation syndrome. On July 14, the HFEA updated the recommendations, and fertility clinics were authorized to resume treatment. ${ }^{112}$

The orientation of the Brazilian National Health Surveillance Agency (Agência Nacional de Vigilância Sanitária-ANVISA), in its most recent technical note on May 12, is to postpone any assisted reproduction treatment until the epidemic is declared controlled in the country by the Ministry of Health, with emphasis on the recommendation of not to proceed with embryo transfer in treatment cycles eventually performed. Cases in which the postponement could cause more damages to the patient were excluded. ${ }^{113}$
Finally, several other countries made their specific recommendations in the field of ARTs, ${ }^{114-116}$ and recently, an international panel of experts identified which patients should be prioritized for fertility care. ${ }^{109}$ According to these authors, advanced-age women (i.e., age 35 years) with low prognosis to ARTs tend to lose their fertility potential faster than other infertile women. Other subgroups of women who should be prioritized are those who need urgent fertility preservation, including women affected by systemic autoimmune disorders who presented a restricted time frame during which fertility preservation is possible. For the authors, once the risk of COVID-19 infection is decreasing, other ART treatment could restart following local regulations. The key principle in ART treatment during phase II is that COVID-19 symptoms should be excluded before and during ART treatment in patients, staff, and anyone attending ART centers. ${ }^{109}$

However, considering that the period of SARS-COV-2 infection is different between countries, it is difficult to follow a single worldwide guide for ARTs. Thus, caution marks the most appropriate recommendation for assisted reproduction centers at this moment: avoiding elective treatment cycles in countries with high transmission levels at least until they have a better epidemiological and clinical outline of the situation. Finally, several important questions about SARS-CoV-2 in ARTs need to be answered, such as follows: the possibility of SARS-CoV-2 transmission at several stages of ARTs, the possibility of viral transmission to embryos conceived in vivo and in vitro, and the repercussions of COVID-19 on embryo implantation or early pregnancy. Such knowledge, among others, will give important support to new and revised recommendations, both for natural conception and for assisted reproduction, including cycles for embryo transfer or those for cryopreservation of oocytes.

\section{CONCLUSION}

False-negative SARS-CoV-2 testing is rare but can occur with inadequate sample collection or if the sample is collected early in the disease course. According to the CDC, ${ }^{117}$ acceptable specimens for RT-PCR include nasopharyngeal, oropharyngeal, nasal mid-turbinate, anterior nares swabs, nasopharyngeal, or nasal washes or aspirates, collected by a trained healthcare professional. Therefore, there are no validated commercial tests based on molecular technology for SARS-CoV-2 detection in samples of the human reproductive tract of male and nonpregnant females. There is limited understanding of how the test results should be interpreted, especially considering that the detection of SARS-CoV-2 RNA in the human reproductive tract of male and nonpregnant female does not necessarily indicate that a replicationcompetent or infectious virus is present. ${ }^{118}$ The detection of viable infectious SARS-CoV-2 is possible using cell culture techniques. In addition, serological tests do not provide further clarity because a negative serum serologic test result does not exclude the possibility of SARS-CoV-2 presence in the human reproductive tract. In addition, there is a potential risk for disease transmission at several stages of ARTs. As COVID-19 is not completely understood, the need for further research confirming and/or refuting these potential routes of transmission remains a priority. Therefore, understanding the mechanisms that underlie persistent SARS-CoV-2 infections in the reproductive tract of male and nonpregnant females is 
crucial to developing guidelines, effective vaccines, and therapies.

This narrative review summarized current information about the impact of SARS-CoV-2 infection in the male and nonpregnant female reproductive tracts (Figure 3 ). It is possible to notice that there are variations regarding the presence of the ACE2 receptor and the virus in the male and nonpregnant female reproductive tracts. Therefore, the studies presented here showed that whether the reproductive tract is a potential target for SARS-CoV-2 infection has not yet been determined. ${ }^{16}$ In addition, little is known about the effect of the SARS-CoV-2 on reproductive health. Overall, all the described studies highlight the importance and the urgency to better understand the presence and persistence of SARS-CoV-2 in the reproductive tract of symptomatic and asymptomatic patients. Several aspects of the possible SARS-CoV-2 sexual transmission need to be elucidated to improve the transmission control measures to protect the population. Considering that the literature is scarce and not yet consensual, new studies are urgently necessary to better establish the natural history of SARS-CoV-2 transmission, pathogenesis, and detection methods in the male and nonpregnant female reproductive tracts. In addition, future studies may clarify the impact of SARS-CoV-2 infection on reproductive health.

Limitations of the study. During the review period, the data on COVID-19 constantly changed with increasing amounts of the literature, both peer-reviewed and non-peer-reviewed.

Received August 28, 2020. Accepted for publication January 7, 2021. Published online January 18, 2021.

Acknowledgment: Publication charges for this article were waived due to the ongoing pandemic of COVID-19.

Financial support: This work was supported by grants from Conselho Nacional de Desenvolvimento Científico e Tecnológico/CNPq, Brazilian government (440521/2016-5), and Departamento de Ciência e Tecnologia da Secretaria de Ciência, Tecnologia e Insumos Estratégicos do Ministério da Saúde/DECIT/SCTIE/MS.

Authors' addresses: Fabrício Morelli, Lyvia E. de F. Meirelles, Maria V. F. de Souza, Natália L. Mari, Cristiane S. S. Mesquita, Camila B. Dartibale, Gabrielle M. Z. F. Damke, Edilson Damke, Vânia R. S. da Silva, Raquel P. Souza, and Marcia E. L. Consolaro, Department of Clinical Analysis and Biomedicine, Laboratory of Clinical Cytology and Semen Analysis, State University of Maringá, Maringá, Brazil, E-mails: fahmorelli@gmail.com, lyvia.fmeirelles@hotmail.com, mariavitoriafesouza@gmail.com, nlmari95 @gmail.com, cristianeshinobu@gmail.com, camiladartibale@gmail.com, gabizago@gmail.com, edilsondamke@gmail.com, vaniasela@gmail.com, raquelpantarotto@gmail.com, and melconsolaro@gmail.com.

This is an open-access article distributed under the terms of the Creative Commons Attribution (CC-BY) License, which permits unrestricted use, distribution, and reproduction in any medium, provided the original author and source are credited.

\section{REFERENCES}

1. Ashour HM, Elkhatib WF, Rahman MM, Elshabrawy HA, 2020. Insights into the recent 2019 novel coronavirus (SARS-CoV-2) in light of past human coronavirus outbreaks. Pathogens 9: 186.

2. Guo YR, Cao QD, Hong ZS, Tan YY, Chen SD, Jin HJ, Tan KS, Wang DY, Yan Y, 2020. The origin, transmission and clinical therapies on coronavirus disease 2019 (COVID-19) outbreak: an update on the status. Mil Med Res 7: 11-21.

3. Coronaviridae Study Group of the International Committee on Taxonomy of Viruses, 2020. The species severe acute respiratory syndrome-related coronavirus: classifying 2019-nCoV and naming it SARS-CoV-2. Nat Microbiol 5: 536-544.
4. World Health Organization, 2020. Coronavirus Disease 2019 (COVID-19) Situation Report-108. Geneva, Switzerland: WHO. Available at: https://apps.who.int/iris/handle/10665/332063? locale-attribute=pt\&. Accessed April 8, 2020.

5. Liu $X$ et al., 2020. Single-cell transcriptome analysis of the novel coronavirus (SARS-CoV-2) associated gene ACE2 expression in normal and non-obstructive azoospermia (NOA) human male testes. Sci China Life Sci 63: 1005-1015.

6. Huang $C$ et al., 2020. Clinical features of patients infected with 2019 novel coronavirus in Wuhan, China. Lancet 395: 497-506.

7. Itelman E et al., 2020. Clinical characterization of 162 COVID-19 patients in Israel: preliminary report from a large tertiary center. Isr Med Assoc J 22: 271-274.

8. Xu Z et al., 2020. Pathological findings of COVID-19 associated with acute respiratory distress syndrome. Lancet Resp Med 8: 420-422.

9. Vetter P, Vu DL, L'Huillier AG, Schibler M, Kaiser L, Jacquerioz F, 2020. Clinical features of COVID-19. BMJ 369: m1470.

10. Kim GU, Kim MJ, Ra SH, Lee J, Bae S, Jung J, Kim SH, 2020. Clinical characteristics of asymptomatic and symptomatic patients with mild COVID-19. Clin Microbiol Infect 26: 948-951.

11. Cascella M, Rajnik M, Cuomo A, Dulebohn SC, Di Napoli R, 2020. Features, evaluation and treatment coronavirus (COVID-19). StatPearls [Internet]. Treasure Island, FL: StatPearls Publishing.

12. Paoli D, Pallotti F, Colangelo S, Basilico F, Mazzuti L, Turriziani O, Antonelli G, Lenzi A, Lombardo F, 2020. Study of SARS-CoV-2 in semen and urine samples of a volunteer with positive nasopharyngeal swab. J Endocrinol Invest 43: 1819-1822.

13. Chen Y, Liu Q, Guo D, 2020. Emerging coronaviruses: genome structure, replication, and pathogenesis. J Med Virol 92: 418-423.

14. Corman VM et al., 2020. Detection of 2019 novel coronavirus (2019-nCoV) by real-time RT-PCR. Euro Surveill 25: 2000045.

15. Chen $\mathrm{H}$ et al., 2020. Clinical characteristics and intrauterine vertical transmission potential of COVID-19 infection in nine pregnant women: a retrospective review of medical records. Lancet 395: 809-815.

16. Wang Z, Xu X, 2020. scRNA-seq profiling of human testes reveals the presence of the ACE2 receptor, a target for SARSCoV-2 infection in spermatogonia, Leydig and sertoli cells. Cells 9: 920-929.

17. Fu J, Zhou B, Zhang L, Balaji KS, Wei C, Liu X, Chen H, Peng J, Fu $J, 2020$. Expressions and significances of the angiotensinconverting enzyme 2 gene, the receptor of SARS-CoV-2 for COVID-19. Mol Biol Rep 47: 4383-4392.

18. Shen Q, Xiao X, Aierken A, Liao M, Hua J, 2020. The ACE2 expression in sertoli cells and germ cells may cause male reproductive disorder after SARS-CoV-2 infection. $J$ Cell Mol Med 24: 9472-9477.

19. Reis FM, Bouissou DR, Pereira VM, Camargos AF, dos Reis AM, Santos RA, 2011. Angiotensin-(1-7), its receptor mas, and the angiotensin-converting enzyme type 2 are expressed in the human ovary. Fertil Steril 95: 176-181.

20. Jing Y, Run-Qian L, Hao-Ran W, Hao-Ran C, Ya-Bin L, Yang G, Fei C, 2020. Potential influences of COVID-19/ACE2 on female reproductive system. Mol Hum Reprod 26: 367-373.

21. Stanley KE, Thomas E, Leaver M, Wells D, 2020. Coronavirus disease (COVID-19) and fertility: viral host entry protein expression in male and female reproductive tissues. Fert Steril 114: 33-43.

22. Vaz-Silva J, Carneiro MM, Ferreira MC, Pinheiro SVB, Silva DA Silva Filho AL, Witz CA, Reis AM, Santos RA, Reis FM, 2009. The vasoactive peptide angiotensin-(1-7), its receptor mas and the angiotensin-converting enzyme type 2 are expressed in the human endometrium. Reprod Sci 16: 247-256.

23. Chadchan SB, Maurya VK, Popli P, Kommagani R, 2020. The SARS-CoV-2 receptor, angiotensin converting enzyme 2 (ACE2) is required for human endometrial stromal cell decidualization. Biol Reprod (Epub, 2020 Nov 18). Available at: https://doi.org/ 10.1093/biolre/ioaa211.

24. Wang X, Dhindsa R, Povysil G, Zoghbi A, Motelow J, HostykJ, Nickols N, Rettig M, Goldstein D, 2020. Transcriptional inhibition of host viral entry proteins as a therapeutic strategy for SARS CoV-2. Preprints. 2020: 2020030360. doi: 10.20944/preprints202003.0360.v1.

25. Zheng M, Gao Y, Wang G, Song G, Liu S, Sun D, Xu Y, Tian Z, 2020. Functional exhaustion of antiviral lymphocytes in COVID19 patients. Cel Mol Immun 17: 533-535. 
26. Li D, Jin M, Bao P, Zhao W, Zhang S, 2020. Clinical characteristics and results of semen tests among men with coronavirus disease 2019. JAMA 3: 208292.

27. Mao $L$ et al., 2020. Neurologic manifestations of hospitalized patients with coronavirus disease 2019 in Wuhan, China. JAMA Neurol 77: 683-690.

28. Guan W et al., 2020. Clinical characteristics of coronavirus disease 2019 in China. New Engl J Med 382: 1708-1720.

29. Peng X, XuX, LiY, Cheng L, Zhou X, Ren B, 2020. Transmission routes of 2019-nCoV and controls in dental practice. Int J Oral Sci 12: 9.

30. Liu H, Liu F, Li J, Zhang T, Wang D, Lan W, 2020. Clinical and CT imaging features of the COVID-19 pneumonia: focus on pregnant women and children. $J$ Infect 80: 7-13.

31. Figueiro-Filho EA, Yudin M, Farine D. 2020. COVID-19 during pregnancy: an overview of maternal characteristics, clinical symptoms, maternal and neonatal outcomes of 10,996 cases described in 15 countries. J Perinat Med 48: 900-911.

32. Yang $X$ et al., 2020. Clinical course and outcomes of critically ill patients with SARS-CoV-2 pneumonia in Wuhan, China: a single-centered, retrospective, observational study. Lancet Resp Med 8: 475-481.

33. Holtmann N, Edimiris P, Andree M, Doehmen C, Baston-Buest D, Adams O, Kruessel JS, Bielfel AP, 2020. Assessment of SARSCoV-2 in human semen-a cohort study. Fert Ster 114: 233-238.

34. MaL, XieW, LiD, Shi L, Mao Y, Xiong Y, Zhang Y, Ming Z, 2020. Effect of SARS-CoV-2 infection upon male gonadal function: a single center-based study. medRxiv 2020.03.21.20037267. Available at: https://doi.org/10.1101/2020.03.21.20037267.

35. Pan F et al., 2020. No evidence of severe acute respiratory syndrome-coronavirus 2 in semen of males recovering from coronavirus disease 2019. Fert Ster 113: 1135-1139.

36. Song C et al., 2020. Absence of 2019 novel coronavirus in semen and testes of COVID-19 patients. Biol Reprod 103: 4-6.

37. World Health Organization, 2020. SARS (Severe Acute Respiratory Syndrome). Geneva, Switzerland: WHO. Available at: https:// www.who.int/ith/diseases/sars/en/. Accessed August 12, 2020.

38. World Health Organization, 2020. Modes of Transmission of Virus Causing COVID-19: Implications for IPC Precaution Recommendations. Geneva, Switzerland: WHO. Available at: https://www.who.int/news-room/commentaries/detail/ modes-oftransmission- of-virus-causing-covid-19-implicationsforipc-precaution-recommendations. Accessed August 12, 2020.

39. van Doremalen $\mathrm{N}$ et al., 2020. Aerosol and surface stability of SARS-CoV-2 as compared with SARS-CoV-1. N Engl $J$ Med 382: 1564-1567.

40. Mukhra R, Krishan K, Kanchan T, 2020. Possible modes of transmission of novel coronavirus SARS-CoV-2: a review. Acta Biomed 91: e2020036.

41. World Health Organization, 2020. Modes of Transmission of Virus Causing COVID-19: Implications for IPC Precaution Recommendations. Geneva, Switzerland: WHO. Available at: https://www.who.int/news-room/commentaries/detail/modesof-transmission-of-virus-causing-covid-19-implications-for-ipcprecaution-recommendations. Accessed September 25, 2020.

42. Guo ZD et al., 2020. Aerosol and surface distribution of severe acute respiratory syndrome coronavirus 2 in hospital wards, Wuhan, China, 2020. Emerg Infect Dis 26: 1583-1591.

43. McArthur L, Sakthivel D, Ataide R, Chan F, Richards JS, Narh CA, 2020. Review of burden, clinical definitions, and management of COVID-19 cases. Am J Trop Med Hyg 103: 625-638.

44. Zhang W et al., 2020. Molecular and serological investigation of 2019-nCoV infected patients: implication of multiple shedding routes. Emerg Microbes Infect 9: 386-389.

45. To KK et al., 2020. Consistent detection of 2019 novel coronavirus in saliva. Clin Infect Dis 71: 841-843.

46. Cao B et al., 2020. A trial of lopinavir-ritonavir in adults hospitalized with severe COVID-19. N Engl J Med 382: 1787-1799.

47. Ferner RE, Murray PI, Aronson JK, 2020. Spreading SARS-CoV2 through Ocular Fluids. Oxford, United Kingdom: Nuffield Department of Primary Care Health Sciences, Centre for Evidence Based Medicine.

48. Sun T, Guan J, 2020. Novel coronavirus and central nervous system. Eur J Neurol 27: e52.

49. Patri A, Gallo L, Guarino M, Fabbrocini G, 2020. Sexual transmission of severe acute respiratory syndrome coronavirus 2
(SARSCoV-2): a new possible route of infection? J Am Acad Dermatol 82: e227.

50. Xu J, Qi L, Chi X, Yang J, Wei X, Gong E, Peh S, Gu J, 2006. Orchitis: a complication of severe acute respiratory syndrome (SARS)1. Biol Reprod 74: 410-416.

51. Scorzolini L, Corpolongo A, Castilletti C, Lalle E, Mariano A, Nicastri E, 2020. Comment on the potential risks of sexual and vertical transmission of coronavirus disease-19 infection 2. Clin Infect Dis 16: ciaa445.

52. Vivanti AJ, Vauloup-Fellous C, Prevot S, Zupan V, Suffee C, Do Cao J, Benachi A, De Luca D, 2020. Transplacental transmission of SARS-CoV-2 infection. Nat Commun 11: 3572.

53. Zaigham M, Andersson O, 2020. Maternal and perinatal outcomes with COVID-19: a systematic review of 108 pregnancies. Acta Obstet Gynecol Scand 99: 823-829.

54. Monteleone G, Sarzi-Puttini P, Ardizzone S, 2020. Preventing COVID-19-induced pneumonia with anticytokine therapy. Lancet Rheum 2: 255-256.

55. Lu R et al., 2020. Genomic characterisation and epidemiology of 2019 novel coronavirus: implications for virus origins and receptor binding. Lancet 395: 565-574.

56. Walls AC, Park YJ, Tortorici MA, Wall A, McGuire AT, Veesler D, 2020. Structure, function, and antigenicity of the SARS-CoV-2 spike glycoprotein. Cell 181: 281-292.

57. Du L, He Y, Zhou Y, Liu S, Zheng BJ, Jiang S, 2009. The spike protein of SARS-CoV--a target for vaccine and therapeutic development. Nat Rev Microbiol 7: 226-236.

58. Du L, Yang Y, Zhou Y, Lu L, Li F, Jiang S, 2017. MERS-CoV spike protein: a key target for antivirals. Expert Opin Ther Targets 21: 131-143.

59. Datta PK, Liu F, Fischer T, Rappaport J, Qin X, 2020. SARS-CoV2 pandemic and research gaps: understanding SARS-CoV-2 interaction with the ACE2 receptor and implications for therapy. Theranostics 10: 7448-7464.

60. Hoffmann $M$ et al., 2020. SARS-CoV-2 cell entry depends on ACE2 and TMPRSS2 and is blocked by a clinically proven protease inhibitor. Cell 181: 271-280.e8.

61. Ou X et al., 2020. Characterization of spike glycoprotein of SARS-CoV-2 on virus entry and its immune cross-reactivity with SARS-CoV. Nat Commun 11: 1620-1632.

62. Tai W, He L, Zhang X, Pu J, Voronin D, Jiang S, Zhou Y, Du L, 2020. Characterization of the receptor-binding domain (RBD) of 2019 novel coronavirus: implication for development of RBD protein as a viral attachment inhibitor and vaccine. Cell Mol Immunol 17: 613-620.

63. Letko M, Marzi A, Munster V, 2020. Functional assessment of cell entry and receptor usage for SARS-CoV-2 and other lineage B betacoronaviruses. Nat Microbiol 5: 562-569.

64. Zou X, Chen K, Zou J, Han P, Hao J, Han Z, 2020. Single cell RNA seq data analysis on the receptor ACE2 expression reveals the potential risk of different human organs vulnerable to Wuhan 2019 nCoV infection. Front Med 14: 185-192.

65. Yan R, Zhang Y, Li Y, Xia L, Guo Y, Zhou Q, 2020. Structural basis for the recognition of SARS-CoV-2 by full-length human ACE2. Science 367: 1444-1448.

66. Tipnis SR, Hooper NM, Hyde R, Karran E, Christie G, Turner AJ, 2020. A human homolog of angiotensin-converting enzyme. Cloning and functional expression as a captopril-insensitive carboxypeptidase. J Biol Chem 275: 33238-33243.

67. Itoyama $S$ et al., 2005. Identifcation of an alternative 5'untranslated exon and new polymorphisms of angiotensinconverting enzyme 2 gene: lack of association with SARS in the Vietnamese population. Am J Med Genet A 136: 52-57.

68. Boehm M, Nabel EG, 2002. Angiotensin-converting enzyme 2: a new cardiac regulator. N Engl J Med 347: 1795-1797.

69. Crackower MA et al., 2002. Angiotensin-converting enzyme 2 is an essential regulator of heart function. Nature 417: 822-828.

70. Donoghue $M$ et al., 2000. A novel angiotensin-converting enzyme-related carboxypeptidase (ACE2) converts angioten$\sin$ I to angiotensin 1-9. Circ Res 87: E1-E9.

71. Zhang Q, Lu S, Li T, Yu L, Zhang Y, Zeng H, Qian X, Bi J, Lin Y, 2019. ACE2 inhibits breast cancer angiogenesis via suppressing the VEGFa/VEGFR2/ERK pathway. J Exp Clin Cancer Res 38: 173-185. 
72. Vavoulidis E, Margioula-Siarkou C, Petousis S, Dinas K, 2020. SARS-CoV-2 infection and impact on female genital tract: an untested hypothesis. Med Hyp 144: 110162.

73. De Paula GA, Palmeira VA, Ribeiro TFS, Costa LB, de Sa Rodrigues KE, Simões ESAC, 2020. ACE2/angiotensin-(1-7)/ mas receptor axis in human cancer: potential role for pediatric tumors. Curr Drug Targets 21: 892-901.

74. Pan PP, Zhan QT, Le F, Zheng YM, Jin F, 2013. Angiotensinconverting enzymes play a dominant role in fertility. Int $J \mathrm{Mol} S \mathrm{Sci}$ 14: 21071-21086.

75. Kowalczuk S, Broer A, Tietze N, Vanslambrouck JM, Rasko JE, Broer S, 2008. A protein complex in the brush-border membrane explains a hartnup disorder allele. FASEB J 22: 2880-2887.

76. Xia S et al., 2020. Inhibition of SARS-CoV-2 (previously 2019$\mathrm{nCoV}$ ) infection by a highly potent pan-coronavirus fusion inhibitor targeting its spike protein that harbors a high capacity to mediate membrane fusion. Cell Res 30: 343-355.

77. South AM, Tomlinson L, Edmonston D, Hiremath S, Sparks MA, 2020. Controversies of renin-angiotensin system inhibition during the COVID-19 pandemic. Nat Rev Nephrol 16: 305-307.

78. Zhou P et al., 2020. A pneumonia outbreak associated with a new coronavirus of probable bat origin. Nature 579: 270-273.

79. Kuba $\mathrm{K}$ et al., 2005. A crucial role of angiotensin converting enzyme 2 (ACE2) in SARS coronavirus-induced lung injury. Nat Med 11: 875-879.

80. Reis AB, Araújo FC, Pereira VM, Dos Reis AM, Santos RA, Reis $\mathrm{FM}, 2010$. Angiotensin (1-7) and its receptor mas are expressed in the human testis: implications for male infertility. $J$ Mol Histol 41: $75-80$

81. Song H, Seddighzadeh B, Cooperberg MR, Huang FW, 2020. Expression of ACE2, the SARS-CoV-2 receptor, and TMPRSS2 in prostate epithelial cells. Eur Urol 78: 296-298.

82. Li N, Wang T, Han D, 2012. Structural, cellular and molecular aspects of immune privilege in the testis. Front Immunol 3: 152-164.

83. Salam AP, Horby PW, 2017. The breadth of viruses in human semen. Emerg Infect Dis 23: 1922-1924.

84. Liu W, Han R, Wu H, Han D, 2018. Viral threat to male fertility. Andrologia 50: e13140.

85. Xu J, Qi L, Chi X, Yang J, Wei X, Gong E, Peh S, Gu J, 2006. Orchitis: a complication of severe acute respiratory syndrome (SARS). Biol Reprod 74: 410-416.

86. Salam AP, Horby PW, 2017. The breadth of viruses in human semen. Emer Inf Dis 23: 1922-1924.

87. Kurscheidt FA, Mesquita CSS, Damke GMZF, Damke E, Carvalho ARBA, Suehiro TT, Teixeira JJV, da Silva VRS, Souza RP, Consolaro MEL, 2019. Persistence and clinical relevance of Zika virus in the male genital tract. Nat Rev Urol 16: 211-230.

88. Joguet $G$ et al., 2017. Effect of acute Zika virus infection on sperm and virus clearance in body fluids: a prospective observational study. Lancet Inf Dis 17: 1200-1208.

89. Kayaaslan B, Korukluoglu G, Hasanoglu I, Kalem AK, Eser F, Akinci E, Guner R, 2020. Investigation of SARS-CoV-2 in semen of patients in the acute stage of COVID-19 infection. Urol Int 104: 678-683.

90. Pavone $\mathrm{C}$ et al., 2020. Italian males recovering from mild COVID19 show no evidence of SARS-CoV-2 in semen despite prolonged nasopharyngeal swab positivity. Int J Impot Res 32: 560-562.

91. Vinson GP, Mehta J, Evans S, Matthews S, Puddefoot JR, Saridogan E, Holt WV, Djahanbakhch O, 1996. Angiotensin II stimulates sperm motility. Regul Pept 67: 131-135.

92. Valdivia A, Cortés L, Beitia M, Totorikaguena L, Agirregoitia N, Corcostegui B, Casis L, Matorras R, Irazusta J, Agirregoitia E, 2020. Role of angiotensin-(1-7) via MAS receptor in human sperm motility and acrosome reaction. Reprod 159: 241-249.

93. Aitken RJ, 2020. COVID-19 and human spermatozoa - potential risks for infertility and sexual transmission. Andrology (Epub ahead of print). DOI: 10.1111/andr.12859.

94. Sengupta P, Dutta S, 2020. Does SARS-CoV-2 infection cause sperm DNA fragmentation? Possible link with oxidative stress. Eur J Contracept Reprod Health Care 25: 405-406.
95. Cabello F, Sánchez F, Farré JM, Angel L, Montejo AL, 2020. Consensus on recommendations for safe sexual activity during the COVID-19 coronavirus pandemic. J Clin Med 9: 2297.

96. Blumenfeld Z, 2020. Possible impact of COVID-19 on fertility and assisted reproductive technologies. Fert Steril 114: 56-57.

97. Henarejos-Castillo I, Sebastian-Leon P, Devesa-Peiro A, Pellicer A, Diaz-Gimeno P, 2020. SARS-CoV-2 infection risk assessment in the endometrium: viral infection-related gene expression across the menstrual cycle. Fertil Steril 114: 223-232.

98. Goad J, Rudolph J, Rajkovic A, 2020. Female reproductive tract has low concentration of SARS-CoV2 receptors. PLOS ONE 15: e0243959.

99. Qiu L, Liu X, Xiao M, Xie J, Cao W, Liu Z, Morse A, Xie Y, Li T, Zhu $L, 2020$. SARS-CoV-2 is not detectable in the vaginal fluid of women with severe COVID-19 infection. Clin Inf Dis 71: 813-817.

100. Cui $P$ et al., 2020. Severe acute respiratory syndrome coronavirus 2 detection in the female lower genital tract. Am J Obste Gynecol 223: 131-134.

101. Falkenhain-López D, Agud-Dios M, Ortiz-Romero PL, SánchezVelázquez A, 2020. COVID-19-related acute genital ulcers. J Eur Acad Dermatol Venereol 34: e655-e656.

102. Yu N et al., 2020. Clinical features and obstetric and neonatal outcomes of pregnant patients with COVID-19 in Wuhan, China: a retrospective, single-centre, descriptive study. Lancet Infect Dis 20: 559-564.

103. Xiao F, Tang M, Zheng X, Liu Y, Li X, Shan H, 2020. Evidence for gastrointestinal infection of SARS-CoV-2. Gastroenterol 158: 1831-1833.

104. Hindson J, 2020. COVID-19: faecal-oral transmission? Nat Rev Gastroenterol Hepatol 17: 259.

105. Cassuto NJ, Marras G, Jacomo V, Bouret D, 2018. Persistence of Zika virus in gradient sperm preparation. $J$ Gynecol Obst Hum Reprod 47: 211-212.

106. Jindal SK, Rawlins RG, Muller CH, Drobnis EZ, 2016. Guidelines for risk reduction when handling gametes from infectious patients seeking assisted reproductive technologies. Reprod Biomed Online 33: 121-130.

107. Yakass MB, Woodward B, 2020. COVID-19: should we continue to cryopreserve sperm during the pandemic? Reprod Biomed Online 40: 905.

108. Perry MJ, Arrington S, Neumann LM, Carrell D, Mores CN, 2020. It is currently unknown whether SARS-CoV-2 is viable in semen or whether COVID-19 damages spermatozoa. Andrology (Epub ahead of print, May 29; 10.1111/andr.12831).

109. Carbone IF, Mangiagalli AC, Farina A, Alviggia C, 2020. A practical approach for the management of obstetric and infertile women during the phase two of the novel coronavirus disease 2019 (COVID -19) pandemic. Eur J Obst Gyn Repr Biol 251: 266-267.

110. American Society for Reproductive Medicine (ASRM), 2020. Patient Management and Clinical Recommendations during the Coronavirus (COVID-19) Pandemic. Available at: https:// www.asrm.org/globalassets/asrm/asrm-content/news-andpublications/covid-19/covidtaskforceupdate1.pdf. Accessed July 1, 2020.

111. Veiga A, Lundin K, Tapanainen J, Gianaroli L, Mocanu E, Ata B, Rautakallio-Hokkanen S, Vermeulen N, 2020. COVID- Coronavirus.19: ESHRE Statement on Pregnancy and Conception. Available at: https://www.eshre.eu/Press-Room/ESHRENews\#COVID19WG. Accessed July 1, 2020.

112. Stewart J, Kasraie J, Burns G, Campbell A, Evans D, Macklon N, Mathur R, 2020. HFEA Coronavirus (COVID-19) Guidance. Available at: https://www.hfea.gov.uk/about-us/news-and-pressreleases/2020-news-and-press-releases/hfea-coronaviruscovid-19-guidance/. Accessed July 1, 2020.

113. Ministry of Health of Brazil. National Health Surveillance Agency (ANVISA), 2020. Technical Note No. 23/2020/SEI/GSTCO/ DIRE1/ANVISA: Guidelines for Performing Assisted Human Reproduction Procedures in the Face of a Coronavirus (SARSCoV-2) Pandemic. Available at: https://www.sbrh.org.br/wpcontent/uploads/2020/05/Nota-TécnicaAnvisa-RHA-e-Covid. pdf. Accessed July 1, 2020. 
114. Braham M et al., 2020. Tunisian recommendations for resumption of reproductive medicine activity in the COVID-19 pandemic. Tunis Med 98: 343-347.

115. Requena A, Cruz M, Vergara V, Prados N, Galliano D, Pellicer A, 2020. A picture of the COVID-19 impact on IVIRMA fertility treatment clinics in Spain and Italy. Reprod Biomed Online 41: 1-5.

116. Vaiarelli A et al., 2020. COVID-19 and ART: the view of the Italian society of fertility and sterility and reproductive medicine. Reprod Biomed Online 40: 755-759.
117. CDC, 2020. Interim Guidelines for Collecting, Handling, and Testing Clinical Specimens for COVID-19. Interim Guidelines for Collecting, Handling, and Testing Clinical Specimens from Persons for Coronavirus Disease 2019 (COVID-19). Available at: https://www.cdc.gov/coronavirus/2019-ncov/ lab/guidelines-clinical-specimens.html. Accessed July 2, 2020.

118. Wölfel $R$ et al., 2020. Virological assessment of hospitalized patients with COVID-2019. Nature 581: 465-469. 